Egyptian Journal of Aquatic Biology \& Fisheries

Zoology Department, Faculty of Science,

Ain Shams University, Cairo, Egypt.

ISSN $1110-6131$

Vol. 25(1): 953 - 963 (2021)

www.ejabf.journals.ekb.eg

\title{
Effectiveness of Sialang Forest Honey in Maleisation of the Platy Pedang Fish (Xiphophorus sp.)
}

Teuku Iskandar Johan* and Muhammad Hasby

Department of Fishery, Faculty of Agriculture, Universitas Islam Riau

J1. Kaharuddin Nasution, Marpoyan, Pekanbaru, Riau 28284, Indonesia

*Corresponding Author: isjhont@agr.uir.ac.id

\begin{abstract}
ARTICLE INFO
Article History:

Received: Dec. 23, 2020

Accepted: Feb. 23, 2021

Online: March 26, 2021

Keywords:

Sialang forest honey;

maleisation;

Platy Pedang;

sintasan

\section{ABSTRACT}

Given that the small population of male Platy Pedang affects its reproduction, this research aims to increase the number of male Platy Pedang by introducing Sialang forest honey and determine the effectiveness of honey in the maleisation of Platy Pedang fish (Xiphophorus sp.). A completely randomised design consisting of four treatments of immersion with Sialang honey dose of $5 \mathrm{~mL}$ for was used, and each treatment was repeated three times. Three-day-old Platy Pedang fish larvae were immersed in the Sialang forest honey solution for 10, 12 and 14 hours. Results showed that immersion in Sialang forest honey can increase the percentage of males, and the 12-hour treatment yielded the highest percentage $(72.05 \%)$. The percentages for the 14- and 10-hour treatments and the control were $69.55 \%, 63.43 \%$ and $58.33 \%$, respectively. The highest survival percentage was $87.00 \%$.
\end{abstract}

\section{INTRODUCTION}

The ornamental fish business is growing rapidly; the trade value in 2002 was approximately $\$ 200$ million by Vannuccini (2004). One of the ornamental fish used is the Platy Pedang (Xiphophorus SP) fish, which comes from the Poeciliidae family (Abasali and Mohamad, 2010). This fish is among the 10 most exported ornamental fish (Priliska 2013). Females and males can reach 12.5 and $10 \mathrm{~cm}$ in size, respectively, and live in a temperature range of $25-28{ }^{\circ} \mathrm{C}$ and $\mathrm{pH}$ between 7.0 and 7.5 by Nugroho (2008). Male Platy Pedang has brighter colours and wider and longer caudal fins with varying shades. These characteristics make males more attractive than females. Therefore, Platy Pedang fish cultivation on a monosex basis is beneficial because of its attractiveness and high selling power.

In addition Chakraborty et al. (2011) stated that fish farming with male monosex systems provides higher yields than mixed cultivation (male and female). Monosex 
farming can be accomplished through sex reversal techniques using synthetic materials (steroid hormones) and natural ingredients. These techniques include immersion by Firmansyah et al. (2016) and Chaves-Pozo et al. (2018), injection by Ahlina et al. (2015)

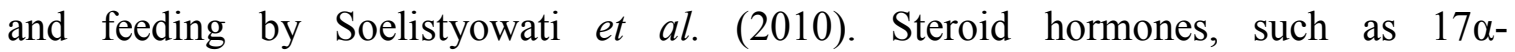
methyltestosterone, has several negative effects, such as carcinogenic effects and environmental pollution by (Sudrajat and Sarida 2006). Moreover, this hormone is expensive and difficult to obtain (Damayanti et al., 2013; Asaduzzaman et al. 2019). Therefore, natural hormone stimulants are safer and more environmentally friendly than synthetic materials Contreras-Sanchez et al. (2001). One of such natural ingredients is honey by Kautsari et al. (2015).

Bee honey is a natural ingredient containing chrysin from a type of flavonoid that acts as an aromatase inhibitor by (Pichichero et al., 2010; Oliveira et al., 2002; Kitano et al., 2000). Honey may replace synthetic hormones in turning a female Platy Pedang into a male and is more environmentally friendly and economical than synthetic androgen hormones and aromatase inhibitors. The use of bee honey has successfully increased the percentage of maleisation in tilapia (Oreochromis niloticus; (Oreochromis niloticus) (Kautsari et al., 2015; Ratnasari, 2014; Odara et al., 2015; Damayanti et al., 2013) and Guppy fish (Poecilia reticulata Peters) by (Soelistyowati et al., 2007; Utomo, 2008). Thus, this study aims to determine the effectiveness of Sialang forest honey in the maleisation of Platy Pedang fish through the larval immersion method.

\section{METHODOLOGY}

This research was conducted in the Laboratory of Aquaculture, Faculty of Agriculture, Riau Islamic University of Riau, Indonesia. The material used was Sialang honey. Three-day-old Platy Pedang fish larvae were obtained from spawning 10 male fish and 30 female fish that were 3-5 and 2-4 cm long, respectively, and had an average weight of $30 \mathrm{~g}$. This study used a completely randomised design consisting of four treatments (control and treatments with immersion times of 10, 12, and14 hours). Five milliliters of L-1 Sialang honey was used, and each treatment was conducted three times. Platy Pedang males and females were kept in separate $60 \mathrm{~cm} \times 35 \mathrm{~cm} \times 35 \mathrm{~cm}$ aquariums. They were fed in the morning, afternoon and evening ad libitum with pellets (40\% protein) and tubifex worms. The platy sword brood was cooked and spawned in a $60 \mathrm{~cm} \times 35 \mathrm{~cm} \times 35 \mathrm{~cm}$ aquarium; 10 males and 30 female parents were spawned for 24 hours. After spawning, the mother fish were returned to the maintenance aquarium. The spawned fish larvae were maintained until they were three days old. Figure 1 shows the picture of Platy Pedang fish under experiment with aerator. 


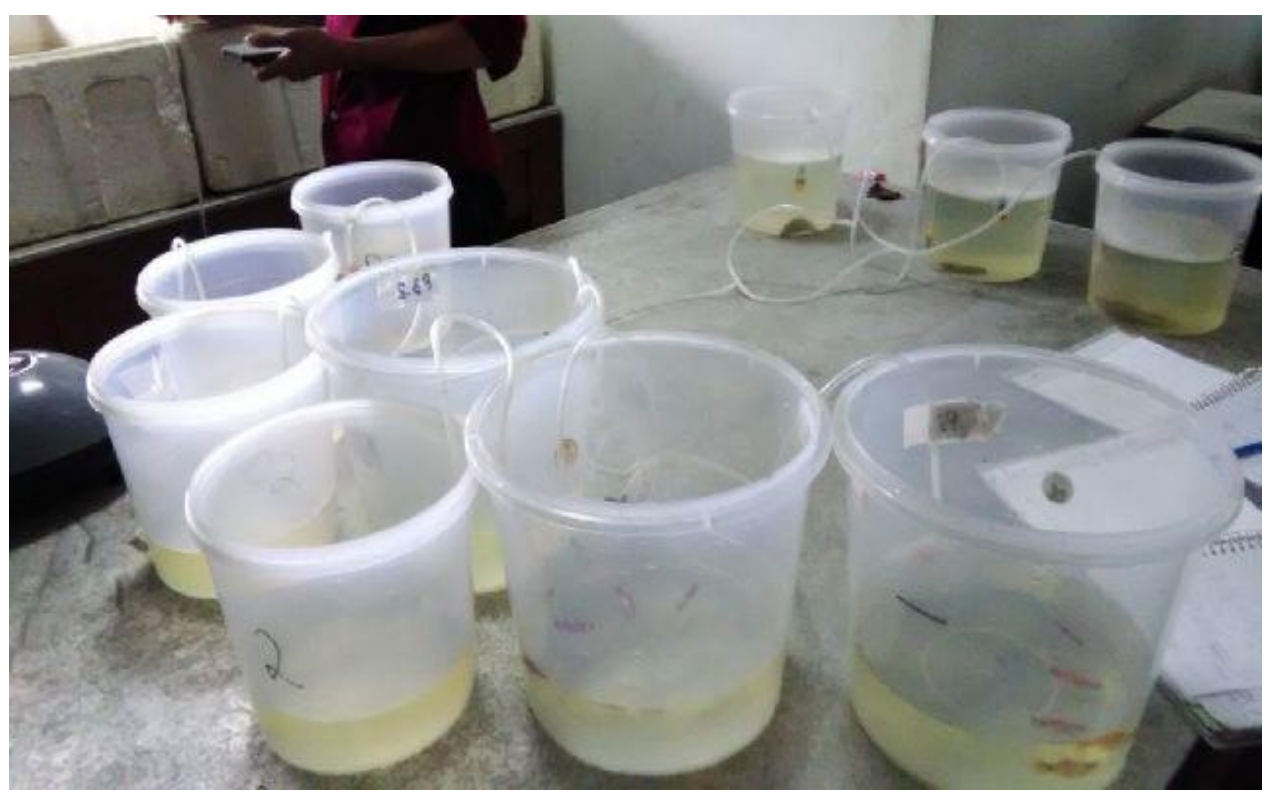

Fig. 1. Fish under experiment in the laboratory with aerator

Soaking was performed by placing three Platy Pedang fish larvae into a $5 \mathrm{~L}$ jar containing the Sialang honey solution prepared according to the treatment dose $(5 \mathrm{~mL} \mathrm{~L}-$ 1) and then aerated. Soaking was performed for 10, 12 and 14 hours. After immersion, the larvae were moved into a $60 \mathrm{~cm} \times 35 \mathrm{~cm} \times 35 \mathrm{~cm}$ maintenance aquarium, and maintenance was conducted for 60 days. During maintenance, the platy fish larvae were fed with tubifex worms until they were 27 days old and then with pellets until they 60 days old. Feeding was performed three times a day ad libitum. Cleaning was conducted every day with a change of water of as much as $10 \%$ to maintain water quality during maintenance. The observed parameters were the percentage of males, survival rate and water quality parameters (temperature, $\mathrm{pH}$, ammonia and dissolved oxygen). The Platy Pedang male sex ratio was determined after the fish were 60 days old through the morphological observation of their secondary characteristics. The results of the examination of the percentage ratios and survival rates were analyzed by using analysis of variance (ANOVA) and completely random pattern RAL. Temperature was measured every day in the morning, afternoon and evening, whereas the $\mathrm{pH}$, dissolved oxygen and ammonia were measured at the beginning and at the end of the study. Figure 2. Platy Pedang (Xiphophorus SP) fish male and female under experiment in the laboratory with aerator. 


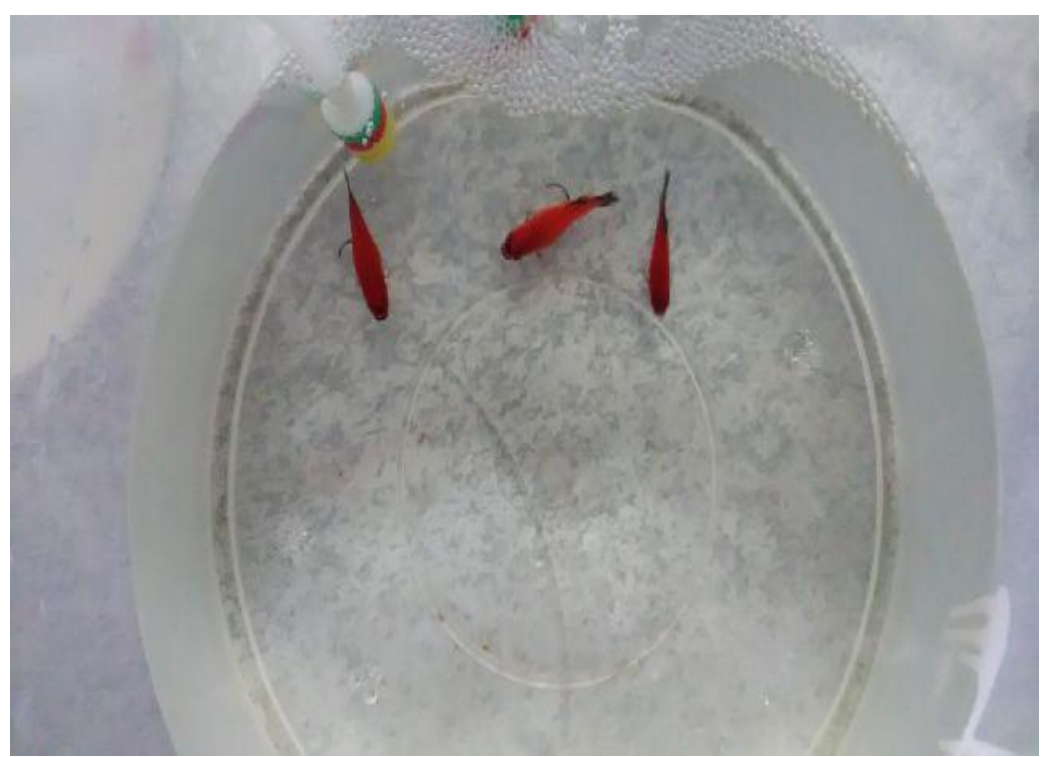

Fig. 2. Platy Pedang (Xiphophorus SP) fish male and female under experiment

\section{RESULTS}

The effects of immersing Platy Pedang fish larvae in Sialang forest honey for different immersion times on the percentage of male fish produced and on survival are shown in Tables 1 and 2.

Table 1. Percentage of maleisation of Platy Pedang fish (Xiphophorus SP)

\begin{tabular}{ccccc}
\hline \multirow{2}{*}{ Repeat } & \multicolumn{4}{c}{ Soak Duration (hour) } \\
\cline { 2 - 5 } & Control & 10 & 12 & 14 \\
\hline 1 & 57.14 & 63.63 & 75.00 & 70.58 \\
2 & 62.50 & 60.00 & 70.58 & 66.67 \\
3 & 58.11 & 64.77 & 71.84 & 68.75 \\
4 & 60.52 & 62.24 & 73.23 & 70.11 \\
5 & 58.33 & 66.66 & 70.58 & 71.42 \\
\hline Total & 177.97 & 190.29 & 216.16 & 208.67 \\
\hline Percentage (\%) & 59.32 & 63.46 & 72.25 & 69.51 \\
\hline
\end{tabular}

The data in Table 1 indicate that the percentage of success of maleisation varied among treatments. The highest percentage $(72.05 \%)$ was obtained at 12 -hour immersion time. The percentages obtained for the 14- and 10-hour immersion treatments were $69.55 \%$ and $63.43 \%$, respectively. The percentage yielded by the control was $58.33 \%$ (no treatment was given, and thus sex development occurred in the fish naturally). The table also shows a decrease in the percentage of maleisation at immersion times exceeding 12 
hours. Therefore, prolonged immersion times reduce the success of maleisation. Figure 3 shows the results of maleisation of Platy Pedang fish.

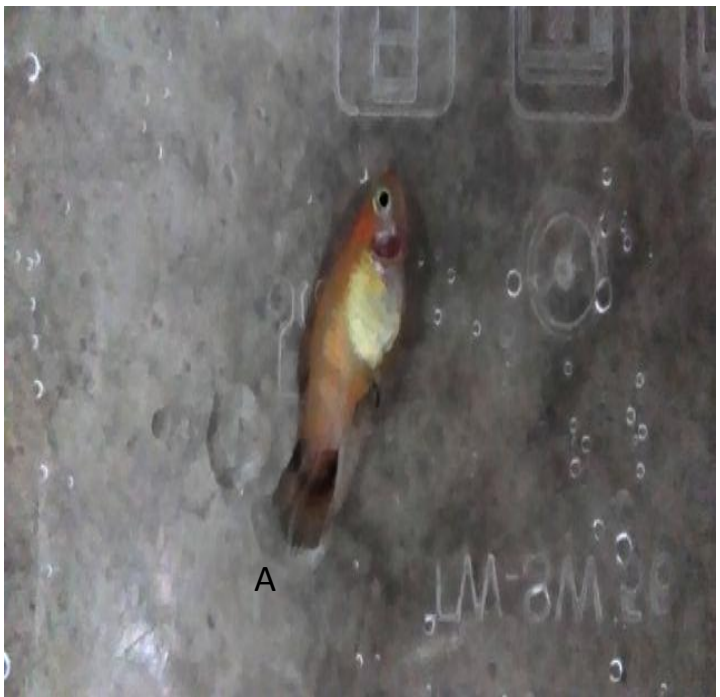

(a)

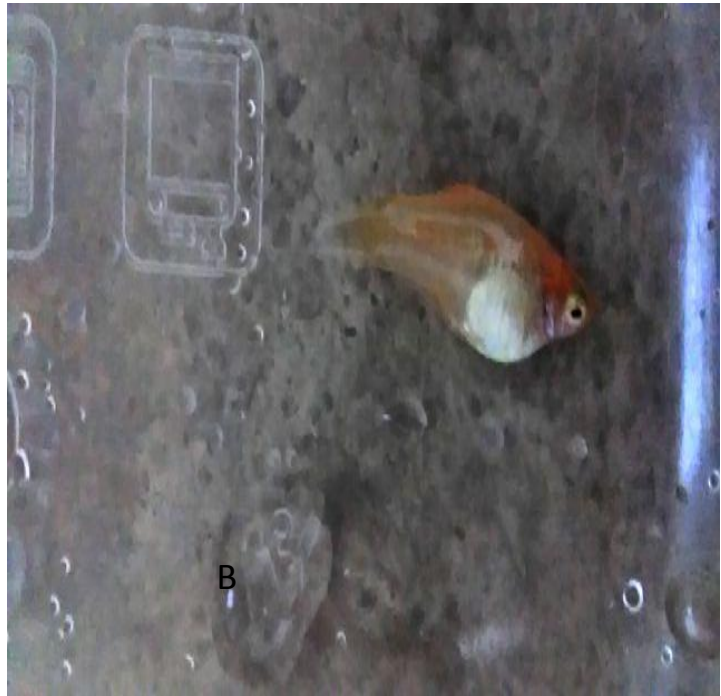

(b)

Fig. 3. Experiment results to the Platy Pedang fish. (a) first sample (b) second sample

The results of the ANOVA obtained Fcount (0.02) $<$ F table (4.75) at the 95\% level means that the effect of the differences in the immersion time of the larvae in the Sialang honey solution on the Platy Pedang fish maleisation was not significantly different at the $95 \%$ level.

Table 2. Survival percentage of Platy Pedang fish (Xiphophorus SP)

\begin{tabular}{ccccc}
\hline \multirow{2}{*}{ Repeat } & \multicolumn{4}{c}{ Soak Duration (hour) } \\
\cline { 2 - 5 } & Control & 10 & 12 & 14 \\
\hline 1 & 72.22 & 88.88 & 83.33 & 55.55 \\
2 & 83.33 & 94.44 & 88.88 & 50.00 \\
3 & 70.43 & 87.19 & 85.44 & 61.23 \\
4 & 74.56 & 83.32 & 89.51 & 71.35 \\
5 & 61.11 & 72.22 & 88.88 & 94.44 \\
\hline Total & 216.67 & 255.55 & 261.11 & 200.00 \\
\hline Percentage (\%) & 72.33 & 85.21 & 87.20 & 66.51 \\
\hline
\end{tabular}

The data in Table 2 show the difference in survival percentages among the treatments. The highest percentage of survival was $87 \%$ and found in the 12 -hour immersion treatment. The second highest percentage was $85.16 \%$, which was obtained from the 10-hour immersion treatment. In the control treatment, the percentage of the 
limit was $72.22 \%$, and the lowest percentage of survival $(66.67 \%)$ was found in the 14 hour immersion treatment. Figure 4 shows another experiment of Platy Pedang fish.

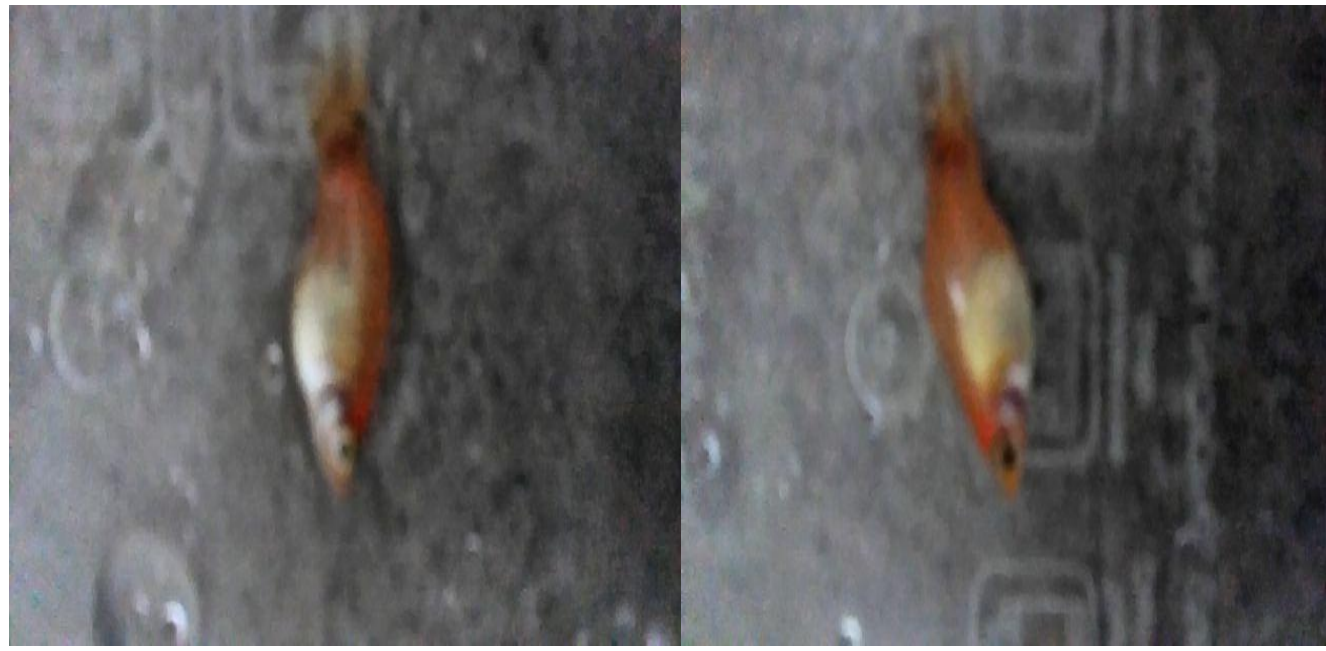

(a)

(b)

Fig. 4. Another experiment results to the Platy Pedang fish.

(a) first sample (b) second sample

The results of the ANOVA obtained Fcount (0.04) <F table (4.75) at the $95 \%$ level. Thus, the effect of the difference in the immersion time of the larvae in the Sialang honey solution on platy fish maleisation was not significantly different at the $95 \%$ level of survival. Platy Sword Fish. The results of the water quality parameter measurements in the study included temperature, $\mathrm{pH}$, dissolved oxygen and ammonia $\left(\mathrm{NH}_{3}\right)$, as shown in Table 3. The measurements in the table show that the temperature ranged from $28^{\circ} \mathrm{C}$ to $32^{\circ} \mathrm{C}$, the water acidity $(\mathrm{pH})$ was between 6.5 and 7 , the dissolved oxygen content ranged from $4.8 \mathrm{ppm}$ to $5.4 \mathrm{ppm}$ and the ammonia content was between 0.08 and $0.58 \mathrm{ppm}$.

Table 3. Measurement of water quality parameters in this research

\begin{tabular}{c|c}
\hline Parameter & Range \\
\hline Temperature & $26{ }^{\circ} \mathrm{C}-29^{\circ} \mathrm{C}$ \\
Acidity $(\mathrm{pH})$ & $6.5-7.0$ \\
Dissolved Oxygen (DO) & $4.8-5.4 \mathrm{ppm}$ \\
Ammonia $\left(\mathrm{NH}_{3}\right)$ & $0.08-0.58 \mathrm{ppm}$ \\
\hline
\end{tabular}




\section{DISCUSSION}

Sex reversal technology is a monosex production technique that implements hormonal engineering to change sexual character from female to male (masculinisation) or from male to female (feminisation) by Damayanti et al. (2013). This process can occur during sex differentiation, when the embryonic brain is still in a phenotypic bi-potential state in genital formation morphological, behavioral and functional; by Borg (1994). In Arfah (1997) stated that sex differentiation in fish is not finalized in the initial development phase of the embryo or larvae. (Devlin and Nagahama 2002) added that fish sex differentiation is influenced by internal (genetic) factors, external (environmental) elements and secondary interactions. The genetic factors that influence the direction of sex differentiation include hormonal systems (en-dokrin) and the action of genes on chromosomes and autosomes. Environmental influences include the addition of certain materials, such as hormones and chemicals and the physical-chemical conditions of the media for maintaining fish during the period of genital labile. This study shows that the use of $5 \mathrm{~mL} \mathrm{L-1} \mathrm{Sialang} \mathrm{forest} \mathrm{honey} \mathrm{and} \mathrm{different} \mathrm{immersion} \mathrm{times} \mathrm{(10,} 12$ and 14 hours) can increase the percentage of Platy Pedang fish maleization, and each treatment generated different results. Honey contains chrysin from a type of flavonoid that acts as an aromatase inhibitor (Devlin and Nagahama 2002) and (Pichichero et al., 2010; Oliveira et al., 2002; Kitano et al., 2000). According to Dean (2004), natural aromatase inhibitors result in increased production of testosterone, thereby promoting the dominance of male characteristics.

Aside from honey, potassium can be used to turn female fish into males; potassium converts fat into prenegnelon, which converts estrogen into progesterone by Odara et al. (2015). Honey enters the body of fish larvae through the gills, skin and lateral lines through the diffusion process during immersion Dean (2004). Diffusion is the process of directing particles of a solid, liquid or gas substance from a high-concentration area to a low-concentration one through the membrane of the sex cell (core cells). According to Tang (2002), core cells are peptide organelles in cells that function as warehouses of genetic material and thus play a role in generating offspring. In this study, 12 hours was the optimal immersion time for the larvae. This study shows that immersing larvae in Sialang honey yielded a higher percentage of males than the percentage in the control (from $59.32 \%$ to $63.43 \%-72.05 \%$ ). The highest percentage of maleisation success $(72.05 \%)$ was found in the 12-hour treatment. Different results were obtained by Kautsari et al. (2015) in tilapia with the same immersion time; they obtained a $96.33 \%-98.89 \%$ percentage of male fish, whereas their immersion of guppy fish showed the highest yield of $100 \%$. This difference in results was caused by variations in the dosage used (10-30 $\mathrm{mL} \mathrm{L-1} \mathrm{for} \mathrm{tilapia} \mathrm{and} \mathrm{20-40} \mathrm{mL} \mathrm{L-1} \mathrm{for} \mathrm{guppy} \mathrm{fish).}$

The 14-hour immersion treatment in the current study obtained a percentage of $69.55 \%$. This result may be due to the prolonged immersion time. The given dose was not 
expected to be in accordance with the immersion time, thereby causing the fish to become stressed. This condition affected the diffusion process in the fish body, thereby reducing the percentage of maleisation in treatment P3. The same result was suggested by Kautsari et al. (2015) stress and die of fish, but an exceedingly low dose will decrease the capability of hormones to reverse sexes. In the 10-hour immersion treatment, the percentage produced was $63.43 \%$, which was lower than that of the 12-hour immersion time. The immersion time was extremely short for the diffusion of honey into the Platy Pedang larvae to be completed. This result is in accordance with that of by Odara et al. (2015), who obtained a male percentage of $80 \%$. However, the percentage of male sex success was still low compared with that of the 12-hour immersion treatment. In addition, the control treatment obtained $58.33 \%$. The fish larvae were not given any treatment, thereby enabling sex development to occur naturally. This finding is supported by Piferrer and Donaldson (1992), who stated that soaking larvae in hormones for short times causes ineffective absorption of hormones into the body, whereas immersion for prolonged periods causes a paradoxical effect.

In sex reversal studies on feminization and masculinization, hermaphrodite or intersex individuals are generally found. For instance, in Misgurnus mizolepis fish soaked in low doses $(50-200 \mu \mathrm{g} / \mathrm{L}), 0.7 \%-4.7 \%$ are intersex individuals by Jo et al. (1997). By contrast, no intersex individuals were found in the present study. According to (Hunter and Donaldson 1983), the success of changing sex is determined not only by the type and dosage of hormones used but also by the duration of hormone administration, species, treatment period and hormone administration. The length of immersion time greatly influences the sex reversal of fish; a short immersion time will compromise the process of directing the sex change. The dose is usually associated with the length of treatment. High doses are usually given in a short time, whereas low doses are given for long periods Zairin (2002). The percentage of Platy Pedang survival after the treatment was not significantly different. Survival rate in the 12-hour immersion treatment was higher $(87.00 \%)$ than the survival rates in the other treatments. The lowest survival rate was obtained in the 14-hour immersion group. This finding indicates that a long immersion time tends to reduce the survival of Platy Pedang fish. The 10-hour immersion time produced a survival percentage of $85.16 \%$, which is higher than the percentage obtained by Odara et al. (2015) in tilapia; their soaking of fish with the same dose and time produced a survival rate of only $76.66 \%$, whereas their control treatment obtained a survival of $72.22 \%$.

\section{CONCLUSION}

The population of maleisation Platy Pedang fish (Xiphophorus sp.) can be increased by soaking Platy Pedang larvae in $5 \mathrm{~mL}$ of L-1 Sialang forest honey. Different immersion times can increase the percentage of produced males to $72.05 \%$, and the 
highest percentage of survivors was $87.00 \%$. The 14-hour immersion treatment obtained a percentage of only $69.55 \%$ possibly because of the prolonged immersion time. Therefore, the use of Sialang forest honey is effective in the maleisation of Platy Pedang fish and increases species population.

\section{ACKNOWLEDGMENT}

The authors would like to say thank you very much to Universitas Islam Riau for funding this research Grant throughout internal grant with contract no.113/KONTRAK/LPPM/4-2019.

\section{REFERENCES}

Abasali, H. and Mohamad, S. (2010). Effect of Dietary Probiotic Level on the Reproductive Performance of Female Platy Xiphophorus maculatus. Research Journal of Animal Sciences 4(5): 112-116.

Ahlina, H.; Sudrajat, O.A.; Budiardi, T. and Affadi, R. (2015). Induksi Pematangan Gonad Secara Hormonal pada Ikan Sidat, Anguilla bicolor bicolor McClelland 1844 dengan Penggunaan Pregnant Mare Serum Gonadotropin, Anti Domapmin, dan Recombinant Growth Hormone. Jurnal Ikhtiologi Indonesia 15(3): 209-221

Arfah, H. (1997). Efektifitas Hormon 17 $\alpha$-metiltestosteron dengan metode Perendaman Induk Terhadap Nisbah Kelamin dan Feretilitas Keturunan Ikan Gapi (Poecilia reticulata). Master, Institut Pertanian Bogor.

Asaduzzaman, M.; Noor, A.R.; Rahman, M.M.; Akter, S.; Hoque, N.F.; Shakil, A. and Wahab, M.A. (2019). Reproductive Biology and Ecology of the Green Mussel Perna viridis: A Multidisciplinary Approach. MDPI Biology 8(4): 88.

Borg, B. (1994). Androgen in teloist fish. Com-parative Biochemistry and Physiology 109(3): 219-245.

Chakraborty, S.B.; Mazumdar, D.; Chatterji, U. and Ba-nerjee, S. (2011). Growth of mixed-sex and monosex nile tilapia in different culture systems. Turkish Journal of Fisheries and Aquatic Sciences 11(3): 131-138.

Chaves-Pozo, E.; García-Ayala, A. and Cabas, I. (2018). Effects of Sex Steroids on Fish Leukocytes. MDPI Biology 7(1): 9.

Contreras-Sanchez, W.M.; Fitzpatrick, M.S. and Schreck, C.B. (2001). Fate of Methyltestosterone in the Pond Environment: Impact of MT-contaminated soil on Tilapia sex differentiation. 9th Work Plan,Effluents and Pollution Research 2C (9ER2C), Final Report. In: Gupta A, McElwee K, Burright J, Cummings X and Egna H (Eds). 18th Annual Technical Report. PD/A. CRSP. Corvallis. Oregon, Oregon State University: 83-86.

Damayanti, A.; Sutresna, A. and Wildn, W. (2013). Aplikasi madu untuk pengarahan jenis kelamin pada ikan nila (Oreochromis niloticus). Depik 2(2): 82-86.

Dean, W. (2004). Chrysin: Is it an effective aromatase inhibitor. Vitamin Research News 18(4): 51-58. 
Devlin, R.H. and Nagahama, Y. (2002). Sex determina-tion and sex differentiation in fish: an overview of genetic, physiological, and enviromental influences. Aquaculture 208(3): 191-364.

Firmansyah, R.; Carman, O. and Soelistyowati, D.T. (2016). Ikan Pelangi Iriatherina werneri (Meiken, 1974) dengan Hormon Estradiol-17 $\beta$. Jurnal Ikhtiologi Indonesia 16(3): 269-278.

Hunter, J.E. and Donaldson, E.M. (1983). Hormonal sex control and its application to fish culture. In Fish Physiology (W.S. Hoar, D.J. Randal and E.M. Donaldson, Eds.), vol IX. New York, Academic Press.

Jo, J.Y.; Kim, C.G. and Kim, D.S. (1997). Sex reversal in Mud Loach Misgurnus mizolepis by immersion Pusan, South Korea, Department of Aquaculture, National Fisheries University of Pusan: 5.

Kautsari, N.; Rahma, S. and Syafikri, D. (2015). Pengaruh Perendaman Larva dengan Berbagai Dosis Madu Sumbawa Terhadap Nisbah Jenis Kelamin dan Pertumbuhan Ikan Nila. Jurnal Iktiologi Indonesia 12(2): 99-106.

Kitano, T.; Takumane, K.; Nagahama, Y. and Abe, S. (2000). Aromatase inhibitor and 17a-me-thyltestosterone cause sex-reversal from genetical females to phenotypic males and suppression of P450 aromatase gene ex-pression in japanese flounder (Paralich-thys olivaceus). Molecular Reproduction and Development 56(1): $1-5$.

Nugroho, S. (2008). Analisis Finansial Usaha Ikan Hias Air Tawar Heru Fish Farm di Desa Kota Batu, Kecamatan Ciomas, Kabupaten Bogor. Master, Institut Pertanian Bogor.

Odara, S.S.; Watung, J.C. and Sinjal, H.J. (2015). Maskulinisasi Larva Ikan Nila (Oreochromis niloticus) Melalui Penggunaan Madu dengan Konsentrasi Berbeda." Jurnal Budidaya Perairan 3(2): 1-6.

Oliveira, G.A.R.; Ferraz, E.R.A.; Souza, A.O.; Louren-ço, R.A.; Oliveira, D.P. and Dorta, D.J. (2002). Evaluation of the mutagenic activity of chry-sin, a flavonoid inhibitor of the aromatization process. Journal of Toxicology and Environmental Health 75(16-17): 1000- 1011.

Pichichero, E.; Cicconi, R.; Mattei, M.; Muzi, M.G. and Canini, A. (2010). Acacia honey and chrysin reduce proliferation of melanoma cells through alterations in cell cycle progression. International Journal of Oncology 37(4): 973-981.

Piferrer, F. and Donaldson, E.M. (1992). The compara-tive effectiveness of the natural and a syn-thetic estrogen for the direct feminization of Chinook salmon Oncorhynchus tshawytscha. Aquaculture 106(2): 183-193.

Priliska, H. (2013). Tingkat Kelahiran Ikan Platy Sunset Xiphophorus maculatus, Pada Beberapa Tingkat Suhu Air. Bachelor, Institut Pertanian Bogor.

Ratnasari, W.D. (2014). Pengaruh Umur pada Waktu Perendaman Madu Terhadap Keberhasilan Maskulinisasi Larva Ikan Nila Gift (Genetic Inprovementof Farmed Tilapias). Bachelor, Universitas Negeri Malang.

Soelistyowati, D.T.; Martati, E. and Arfah, H. (2007). Efektivitas Madu Terhadap Pengarahan Kelamin Ikan Gapi (Poecilia reticulata Peters). Jurnal Akuakultur Indonesia 6(2): 155-160. 
Soelistyowati, D.T.; Sudrajat, A.O. and Arfah, H. (2010). Maskulinisasi pada Ikan Nila Merah (oreochromis sp.) Menggunakan Bahan Alami Resin Lebah Melalui Pakan Buatan. Jurnal Akuakultur Indonesia 9(2): 178-183

Sudrajat, A.O. and Sarida, M. (2006). Effectivity of aromatase inhibitor and 17 $\alpha$ metiltestosteron treatments in male production of freshwater prawn (Macrobrachium roserbergii de Man). Jakarta, Aquaculture Indonesian.

Tang, U.M. (2002). Fisiologi Hewan Air. Pekanbaru, UNRI Press.

Utomo, B. (2008). Efektivitas penggunaan aromatase inhibitor dan madu terhadap nisbah kelamin ikan gapi (Poecilia reticulata Peters). Bachelor, Institut Pertanian Bogor.

Vannuccini, S. (2004). Overview of Fish Production, Utilization, Consumption and Trade. FAO, Fishery Information, Data and Statistic Unit. Food and Agriculture. Rome, Italy, Organization of the United Nations: 10.

Zairin, M. (2002). Sex reversal: memproduksi benih ikan jantan atau betina. Jakarta, Penebar Swadaya. 